\title{
A sacralização do feminino nas imagens marianas de marfim
}

\section{Jorge Lúzio ${ }^{1}$}

RESUMO: Nos espaços coloniais do Império português, em seus contextos de encontros e confrontos, nos desafios da alteridade, a experiência intercultural pode ser identificada nas diversidades das iconografias religiosas. Neste artigo observa-se a sacralização do feminino, que, se para o Projeto da Conquista teve em Maria a imagem e o modelo de mulher segundo a fé católica, ambiguamente, em suas representações, vestígios técnicos, estéticos e míticos, aproximou a Mãe de Jesus de divindades femininas de devocional equivalência, de outras matrizes das sociedades colonizadas, conforme se pode comparar na ĺndia portuguesa. A imaginária mariana em marfim, produzida nesta que foi uma matéria-prima símbolo de prestígio e de grande valor comercial, denota as tensões do poder além da polarização e do subjugo do império.

PALAVRAS-CHAVE: Feminino. Índia. Marfim. Maria.

ABSTRACT: In a context permeated by conflicts, among the challenge of otherness, intercultural experiences can be identified in the colonial Portuguese Empire environment through the variety of religious iconography. In this paper, our aim is to analyze the feminine sanctification under two perspectives: if, in one hand, Mary was in the Conquer Project both the paradigm and model of woman according to the catholic doctrine, on the other, ambiguously, in its representation and technical, aesthetic and mythic traces, the Mother of Jesus was compared to female deities from religious matrices belonged to other colonized societies, as seen in the Portuguese India. Produced with ivory, symbol of prestige and great commercial value, the images of Mary represent the tensions for power beyond the polarization and the control of the Portuguese Empire.
1. Docente em História Moderna no Departamento de História e Relações Internacionais da Universidade Federal Rural do Rio de Janeiro - UFRRJ. Doutor em História Social pela Pontifícia Universidade Católica de São Paulo - PUC SP, com pós-graduação em Arte e Cultura Barroca na Universidade Federal de Ouro Preto. Atua no Laboratório de Interlocuções com a Ásia / LIA-FFLCH USP, CNPq e no Grupo de Pesquisa Outros Orientes / UNIFESP-UFRJ, CNPq. Email:<jorgeluzio@ hotmail.com>.

KEYWORDS: Feminine. India. Ivory. Mary. 
2. De acordo com a tradução da Bíblia Sagrada publicada pela Editora Paulus, Bíblia de Jerusalém (2008).

3. Joseph Campbell cita esse fato no discorrer de uma análise sobre a ideia de uma "Mãe de Deus" (2008, p. 46).

4. De acordo com o Evangelho de Mateus, nos capítulos 1 e 2, e no Evangelho de Lucas, capítulo 1 , com referências à infância de Jesus. No capítulo 2 de João, versículos 1-12, sobre as Bodas de Caná, quando Maria informou sobre a falta de vinho, o que segundo o autor, levou Jesus à realização do seu primeiro milagre, a transformação da água em vinho. No Evangelho de Marcos, capítulo 6, versículo 3, Maria é citada como mãe do Nazareno. Ainda em João, capítulo 19 (25-27), Maria é citada aos pés da cruz durante a morte do seu filho. São ainda inúmeras as citações, diretas ou indiretas, nos textos dos quatro evangelistas (BÍBLIA SAGRADA, 2008)

\section{O culto a Maria entre aspectos históricos e correlações de mitos e deusas}

Nenhuma mulher, historicamente, teve tantas representações quanto Maria, segundo a tradição bíblica, filha de Ana e Joaquim, a qual foi cultuada como a mãe de Jesus e personificada em clássicos das artes plásticas, da música e da literatura. Seu nome também é o mais encontrado entre os registros de meninas nas mais diversas culturas do Ocidente, uma evidência da força da sua presença. $\bigcirc$ historiador Jaroslav Pelikan afirmou que a figura de Maria proporcionou e definiu a feminilidade no âmbito teológico cristão (PELIKAN, 2000 p. 15), o que certamente influenciou o papel da mulher no mundo laico. Maria foi a síntese do sentido da piedade ou da devoção religiosa, inspirada nas palavras fazei tudo o que Ele vos disser, por ela proferidas, de acordo com o texto do evangelho de João (Jo 2: 5). ${ }^{2}$ Esse apelo acompanhou os primeiros cristãos e seguiu por séculos afora cada vez mais observado, afirmando o poder e a força da mãe de Jesus Cristo, Maria, como sustentáculo da fé cristã. No século XVI, durante a Contrarreforma, a antiga crença na sua virgindade, com origens no cristianismo primitivo e nos ensinamentos dos primeiros padres da lgreja, ampliou-se em devoções que viriam nos séculos seguintes a se estabelecer através do dogma da Imaculada Conceição, instituído pelo papa Pio IX em 1854, embora fosse já venerada como virgem e mãe entre os séculos VII e XV (BOYER, 2000). A maternidade, na tradição judaico-cristã mencionada desde o mito de Eva, tornou-se o seu principal atributo. Outras mulheres obtiveram destaque nas escrituras sagradas dos livros bíblicos, mas nenhuma foi mais importante que Maria, intitulada a Mãe de Deus, Theotokos, em 431 d.C., no Concílio de Éfeso. ${ }^{3}$

Segundo a tradição religiosa, o seu pai, Joaquim, era da descendência do rei Davi, soberano das doze tribos de Israel, o mais importante dos reis hebreus. Quando jovem, foi comprometida em casamento com José e, de acordo com os evangelistas, fora-the anunciado que ela seria a mãe do Messias, o que já havia sido proferido pelos profetas conforme os escritos da literatura religiosa judaica. Os textos evangélicos de Mateus (1:23-25) e de Lucas (1:26-35) relatam a aparição do anjo Gabriel, que lhe revelou a concepção pelo Espírito Santo, mesmo com a indagação sobre a sua virgindade. Na religiosidade católica, o texto da "Anunciação" foi abreviado na oração da "Ave-Maria", uma confissão da fé mariana. Ainda em Lucas, a sagrada escritura a engrandeceu com o texto denominado "Cântico de Maria", o Magnificat, em que a Virgem da cidade de Nazaré teria recitado um hino de exaltação e júbilo pela graça da concepção do Filho de Deus, o que viria a ser o cerne da sacralização da sua maternidade e, paradoxalmente, da sua virgindade, o princípio de uma veneração que se estendeu e se consolidou no decorrer da história cristã.

Além das várias passagens do Novo Testamento que trouxeram a participação de Maria na vida de Jesus até a sua morte, ${ }^{4}$ a lgreja promoveu o culto mariano assumindo a fala de Jesus, que a deixou sob os cuidados do seu discípulo João, referindo-se aos dois como mãe e filho. Dessa analogia os primeiros padres 
entenderam que estava Maria designada Mãe de toda a humanidade, nas palavras "Mulher eis aí o teu filho! [...] eis aí tua mãe" (Jo 19, 26-27). Não há registros sobre a morte de Maria, que para os cristãos ortodoxos teria "dormitado" e em seguida levada aos céus. A liturgia bizantina celebra na data de 31 de agosto a "dormição de Maria", enquanto, para os católicos, a doutrina romana ensina a "assunção", 5 a subida de seu corpo e alma aos céus, proclamada em dogma pelo papa Pio XII em $1^{\circ}$ de novembro de 1950 na encíclica Munificentissimus Dei, tornando dessa forma a virgindade perpétua, a maternidade divina, a imaculada conceição e a assunção aos céus como verdades incontestáveis da fé da lgreja. Ao longo dos séculos, as devoções marianas estenderam-se para além dos títulos que proclamavam seus atributos divinos, e novos títulos surgiram de acordo com as práticas devocionais de fiéis, de ações catequéticas e espirituais das ordens ${ }^{6} \mathrm{e}$ congregações religiosas e dos fenômenos das aparições da Virgem, seus milagres e suas profecias. Em Portugal, após a Restauração em 1640, Dom João IV proclamou Nossa Senhora da Conceição como Rainha, tornando-a padroeira, promovendo assim o culto da Imaculada.

Das ordens missionárias que difundiram os cultos marianos na evangelização dos povos promovidas no Projeto da Conquista implantado pelos reis católicos junto à autoridade papal durante a expansão europeia, estiveram os religiosos franciscanos, os capuchinhos, os beneditinos, os mercedários, os carmelitas, os dominicanos e os jesuítas, entre outras, os quais propagaram a veneração mariana e as festas religiosas em sua honra nas missões que foram se estabelecendo na América, em África e na Ásia. No comprometimento com a doutrina da lgreja, nos atos litúrgicos, na edificação de templos, conventos e casas de formação, na fundação de vilas e cidades, escolas e recolhimentos, a figura de Maria foi sendo estabelecida como Senhora de todos e, justamente por isso, sobreposta aos cultos de deusas pagãs das culturas autóctones das sociedades cristianizadas pelos missionários nas práticas de conversão. A estratégia surgira na própria Europa com a implementação da religião cristã. A deusa celta, Virgo Paritura, na Gália, que teve um templo cujas ruínas serviram de base para a construção de uma igreja dedicada à Nossa Senhora de Chartres, no século XII, corresponde a um desses exemplos. Em Roma, a igreja de Santa Maria Antiqua, do século V, foi construída sobre o templo de Vesta Mater. Santa Maria do Capitólio ocupou o lugar antes dedicado à deusa Juno nos processos de conversão cristã no Império Romano, quando divindades femininas pagãs foram "substituídas" pela presença da Virgem Maria, como aspecto maternal do Supremo (BOFF, 1979). No Novo Mundo, o fenômeno da aculturação, como foi o caso da relação entre o culto de Nossa Senhora de Guadalupe, no México, e a deusa ameríndia Tonantzin, seguiu o mesmo modelo proselitista de suplantação das deusas dos povos conquistados. É certo que as divindades femininas do panteão greco-romano, assim como as deidades do culto ao feminino entre os povos celtas, egípcios, africanos, pré-colombianos ou asiáticos, revelavam não somente a existência de matriarcados naquelas sociedades, mas também do culto à fertilidade, à colheita,
5. No calendário litúrgico romano, a festa da Assunção de Maria ocorre tradicionalmente no dia 15 de agosto.

6. Ver devoções marianas contemplativas na história da Ordem de São Bento e na Ordem de Nossa Senhora do Monte Oliveto. 
7. Na perspectiva de um sistema religioso complexo que inclui distintas escolas de pensamento e diversas vertentes de manifestações religiosas, linhagens e cultos, historicamente amalgamados no subcontinente indiano, estruturados nos princípios do "Sanatana Dharma" (lei eterna ou ordem universal), fundamentado nas escrituras védicas e consolidado no período bramânico (3000 a.C.).

8. Em seu ensaio interdisciplinar, Leonardo Boff analisou sob a perspectiva teológica as questões do feminino e da "mariologia" na dimensão histórica e mitológica.

9. Há uma vasta bibliografia sobre esse missionário. $\mathrm{Pa}$ ra a leitura da sua biografia e conjeturas da sua ação catequética, privilegiamos as pesquisas de Patrícia de Souza Faria (2004).

10. Cf. Mateo Ricci (2010) e Jonathan Spence (1986).

11. Esta crença postula a existência de várias divindades, mas atribui a criação de todas a uma divindade suprema, que seria objeto de culto. De acordo com algumas escolas de pensamento mais ou menos ortodoxas, poderá haver henoteísmos mais próximos do politeísmo ou do monoteísmo que, nesse caso, configura o hinduísmo do período histórico que abordamos, um único Deus que se manifesta e interage com os seres humanos numa grande variedade de aspectos e avatares de variadas aparências e personalidades. Sobre um aprofundamento do conceito, ver os estudos do filólogo e orientalista alemão Max Müller (1823-1900).

12. Essa escola foi difundida pelo grande imperador Açoka (273, 232 a.C.), da dinastia Maurya, cujo avô, Chandragupta Maurya, então contemporâneo da invasão de Alexandre, fundou o às águas e à reprodução da vida, analogicamente vinculados aos papéis atribuídos às mulheres enquanto mães, provedoras, soberanas e guerreiras. Para Benjamim (2008, p. 1 10), a percepção das semelhanças, portanto, parece estar vinculada a uma dimensão temporal e, nesse sentido, o feminino sacralizado no mito vem historicamente sendo estudado nas complexidades das mais distintas culturas.

Nas cosmovisões do hinduísmo ${ }^{7}$ e do budismo, tradições milenares da Índia, a presença das deusas esteve estruturada num amplo leque de divindades femininas que se abriu para os missionários portugueses do século XVI. ${ }^{8}$ Para jesuítas como Roberto de Nobili (1577-1656)9 e Mateo Ricci (15521610), ${ }^{10}$ o que era visto oficialmente como heresia tornou-se aculturação, apropriação, na medida em que seus métodos inovadores e controversos de trabalho de evangelização admitiam aproximações e correlações da fé cristã com as crenças locais, apesar de o monoteísmo católico ter ido de encontro com as religiões da Índia antiga, tidas como politeístas. Nessa perspectiva, o hinduísmo deve ser compreendido como uma religião historicamente henoteísta, ${ }^{11}$ - que explicaria a diversidade de papéis exercidos pelas divindades, inclusive em funções tipicamente femininas, como o ensino das artes, associado à deusa hindu Saraswati. Para o budismo, no caso da escola Theravada, ${ }^{12}$ a mulher enquanto divindade mostrou-se em Tara, a mãe da compaixão, o aspecto feminino do Buda. Em cada povo ou cultura asiática em que o budismo se expandia, novos arquétipos de matriarcas ou soberanas foram se transformando em deidades que, a partir do binômio fecundidade/sacralidade, expressavam-se em novas formas da deusa. Nas missões da China, em Macau, Kuan Yin ou Guanyin, a deusa da misericórdia cuja simbologia advinda de uma divindade tradicionalmente oriunda do budismo indiano, Bothisattva Avalokiteswara, deu origem a outras representações de divindades femininas asiáticas, como a deusa Kannon, conhecida no Japão, também ocupado no expansionismo europeu pelos missionários católicos nos séculos XVI e XVII.

Encontra-se no hinduísmo a ideia da deusa manifestada na terra, Prithivi, conceito que Eliade apresenta como Terra Mater (ELLADE, 200 1). Nessa tradição, a terra é vista como mãe, uma vez que forma o corpo do filho com o material de seu próprio corpo, fazendo emergir de si mesma a vida. Nos textos védicos, base religiosa hindu, o feminino é compreendido como Shakti, energia cósmica encontrada em todos os seres vivos, ou Bhumi, quando representada com flores, frutos e sementes. A Shakti era o princípio feminino da criação na formação das criaturas, sacralizada nas inúmeras formas de Devi ou Mahadevi, ${ }^{13}$ a grande deusa. Esse culto surgiu no II milênio antes de Cristo entre as populações de agricultores autóctones de Harappa e Mohenio-Daro, no Vale do Indo (RAVERI, 2005), berço da civilização hindu. Com a chegada das tribos dos árias, que tiveram em seu panteão divindades masculinas de natureza celeste - Indra, Mitra e Varuna, entre outros -, práticas religiosas se fundiram e a figura da deusa passou a ser cultuada nas colheitas, com santuários erguidos em palácios ou próximos aos vilarejos. Essas reflexões são apresentadas por Massimo Raveri ao lembrar que, 
com as especulações do tantrismo ${ }^{14}$ e do movimento bhakti, ${ }^{15}$ a deusa ou "mãe divina", aclamada como Gauri, ${ }^{16}$ assumiu novos simbolismos quando especulações filosóficas a representaram como consorte(s) dos deuses. A matriz do todo fenomênico, Devi, ${ }^{17}$ esteve então repetida ou reproduzida nas principais deidades femininas do panteão hindu. Além da Saraswati, consorte do deus Brahma, o primeiro da tríade hindu, Devi fora representada em Laksimi, deusa da prosperidade, consorte do deus Vishnu, o preservador, ${ }^{18}$ e Parvati/Uma, esposa de Shiva, ou ainda Durga ou Kali, cujos cultos foram associados a esse mesmo deus.

Nesse complexo campo de arquétipos, mitos e símbolos, a missionação portuguesa no sul da Índia se desenvolveu, impondo novos valores e imagens que se defrontaram com um imaginário considerável, dilatado de representações e metáforas sobre a divindade em plásticas femininas, e absorvendo os dualismos cristãos e hindus.

Muitas das imagens de Nossa Senhora ganharam formas próximas das divindades indianas ou até alguns dos seus atributos. É o caso da flor de lótus, tal como a deusa Lakshimi ou Parvati, o que é relativamente frequente, e não só no campo da escultura. Igualmente o réptil que pisa pode ser influenciado pela iconografia hindu, posto que, na cristã, a Virgem tenha um sob os pés, como acontece com Nossa Senhora da Conceição, vulgaríssima a partir do início do século XVII; só que no cristianismo Maria vence a Serpente do Mal, e no hinduísmo é um crocodilo o veículo privilegiado dos deuses. (DIAS, 2008, p. 266-268)

A flor de lótus, esse emblema peculiar da estética indiana associado à figura das deusas, era repleta de significados de transcendência. Evocava as flores aquáticas que desabrocham em cores e perfumes ímpares, numa analogia dos valores espirituais que, para o místico do Oriente, convidava à superação da condição humana em favor da perfeição espiritual. Embora seja comum nas representações de Lakshimi, foi encontrada esculpida no pedestal de uma imagem de Nossa Senhora (SANTOS, 2002) em marfim, uma alusão à pureza. Lakshimi em suas várias formas ${ }^{19}$ - tradicionalmente oito personificações - sempre esteve sentada sobre essa flor. Essas referências foram encontradas não só em hinos e mantras, mas também em esculturas templárias ou ruínas de antigos templos, onde foram vistas ao lado de Vishnu ou erguidas em posturas sinuosas. As mesmas curvas são encontradas nos cabelos da Virgem ou nos fartos entalhes dos seus mantos. De tal modo que terra e água eram símbolos essencialmente femininos, e desses a relação com a flor de lótus. Sobre o lótus, Zimmer sustenta:

[...] Laksmi sempre que possível (é) associada ao símbolo do lótus. É venerada como "a nascida do lótus" (padmasambhava), "a que está de pé sobre o lótus" (padmesthita), "a que tem a cor do lótus" (padmavarna), [...], "a dos olhos de lótus" (padmaksi), "a abundante de lótus" (padmini, puskarnini). [...] Como deusa protetora do cultivo de arroz da Índia nativa, ela é chamada "Aquela que tem a posse do esterco (karisini)". [...]. Chamam-na de harivallabha e visnupatni, "A Amada Esposa de Visnu". (ZIMMER, 1989, p. 78) império homônimo em 322 a.C., na região central-norte da Índia. Com a capital de Magadha para Pataliputra, atual Patna, Açoka converteu-se ao budismo após testemunhar uma batalha especialmente sangrenta. Erigiu monumentos religiosos, construiu templos, propagou o dharma - princípios filosóficos de uma lei universal, e o império se expandiu para a maior parte do subcontinente indiano, incluindo o litoral ocidental sul e o Ceilão (Sri Lanka), regiões que foram, na Conquista, territórios portugueses. Segundo Roberts (2001, p. 297) Açoka promoveu o comércio com a África e com o Império Romano, tornando-o, junto com a agricultura, uma das principais bases econômicas da Antiguidade indiana.

13. O prefixo maha é utilizado sempre que se quer ressaltar o poder e a força de um deus.

14. Doutrina esotérica baseada em uma revelação diferente, em parte, daquela dos Vedas. Antiquíssimas práticas de cultos autóctones, talvez dravídicos, fundiram-se graças ao desafio das visões místicas com as tradições extáticas dos xamãs centro-asiáticos com as disciplinas religiosas. Tornou-se uma corrente religiosa autônoma entre os séculos VI e VII e difundiu-se também nos centros de cultura e de saber tradicional do hinduísmo que testemunharam o florescer da literatura tântrica. Alguns autores sugeriram uma leitura política para o tantrismo enquanto contestação do bramanismo. Ver Massimo Raveri (2005. p. 79).

15. Em sentido literal, o vocábulo é traduzido por amorosidade ou devoção. Aqui apresentamos no sentido de expressão religiosa característica das práticas vishnuitas ou shivaítas. 
16. Essa expressão aparece em hinos védicos, a Amarela, Sakambhari, a que traz os vegetais, Vindhyavasini, a que habita nos montes.

17. Em invocações de cura e práticas de meditação hindu, devotos a veneram como Gayatri.

18. Entre os avatares de Vishnu, as consortes de $R a$ ma (Sita) e de Krishna (Radha) não estão associadas à Devi, sendo simbolicamente expressões da alma humana (criatura) que se vê, na percepção mística, angustiadamente enamorada pelo seu Criador.

19. É curioso notar na representação de Santhana Lakshmi, umas das suas oito formas, a deusa sobre o lótus portando um menino em seus braços. Desta forma, a ideia da maternidade fica assim elucidada, tal como na Virgem.

20. Este quadro indica a possibilidade de oficinas artísticas que trabalhavam o marfim, também por religiosos franciscanos e dominicanos, além dos próprios jesuítas que, segundo Boxer (1980. p. 75), foram os ativos comerciantes de marfim.

21. A priori, atribuímos a esse sentido um simbolismo da oralidade como prática de fundamental importância nas tradições religiosas do Oriente.
Em todas as representações da Virgem, os "olhos de lótus" podem ser vistos na fisionomia oriental em que ela fora retratada, visivelmente amendoados. Esse traço foi predominante em todo o período da produção iconográfica do marfim. Nas imagens sino-portuguesas, esta era uma característica inconfundível. É desse estilo também a presença do akshamala ou japamala, um rosário de contas usado por hindus e budistas na recitação de preces e mantras. A mesma insígnia é comparada ao rosário ou terço mariano nas imagens de Nossa Senhora do Rosário. Nas representações de Nossa Senhora da Conceição, o gesto das mãos unidas em atitude devocional foi decodificado no anjali mudra UANSEN, 1993, p. 23) (que além de prece simboliza saudação ou namastê, namaskaran - cumprimento de sentido religioso), uma das inúmeras posições de mãos codificadas em tratados de ioga, descritos também em textos clássicos que normatizavam a arte da dança, da dramaturgia e da escultura hindu. Também chamados de hastas, este em particular tivera o mesmo significado de reverência espiritual ou atitude de oração nas duas tradições.

É certo que a difusão do culto mariano na Índia ganhou força com a atuação dos franciscanos e dominicanos que tradicionalmente se rivalizavam no louvor à Mãe de Deus. Essas ordens tiveram um fecundo trabalho nas missões. No entanto, a coabitação pacífica não prevaleceu após as primeiras décadas da evangelização. O fortalecimento da Companhia de Jesus em meio às tensões com o Padroado Português, as conjunturas econômicas e os desafios da evangelização incentivaram a competitividade entre as ordens. ${ }^{20}$ As iconografias e a cultura material religiosa tornaram-se objetos de catequese e de comércio, copiadas dos modelos europeus. Muitas trouxeram em suas composições elementos asiáticos. Um exemplo pode-se notar nas imagens esculpidas com as orelhas descobertas. ${ }^{21}$ Sobre essa particularidade, Santos explicou que:

Essa característica, se foi própria dos modelos levados da Europa para serem copiados, relaciona-se, também, ao mito da inteligência cósmica, percepção dos sons inaudíveis, obediência à palavra divina. No livro "O pensamento do Extremo Oriente", de Murillo Nunes de Azevedo, encontramos: "Diz ainda a tradição hindu que os Vedas foram transmitidos 'da boca para o ouvido' (ouvido interior). Do mestre ao discípulo, que era obrigado a decorá-los integralmente. Os Vedas são os chamados Sruti, isto é, 'o que tem de ser ouvido'. Estariam as orelhas descobertas vinculando a relação audição-aprendizado? Estariam fundamentos místicos orientando a observância de preceitos que se estruturam em costume nessa cultura voltada para o sagrado?" (SANTOS, 2002)

O sagrado foi uma das tônicas do período seiscentista nos processos de conversão das almas no mundo português. Um sagrado que não escondeu os propósitos da colonização e que se diferenciava do sentido de sacralidade praticado no Oriente, que estava enraizado nas práticas e significações daquelas sociedades. Nesse sentido, são díspares por serem reflexos de culturas que, 
embora imbuídas dos valores universais, promoveram a suposta supremacia europeia sobre as Índias orientais.

Para uma abordagem comparativa, na devoção à Virgem prevaleceu a ambiguidade do seu caráter materno. São inúmeros os seus títulos em cujas esculturas votivas houvera a presença do Menino Jesus. Foi o caso das imagens de Nossa Senhora do Rosário, Nossa Senhora da Anunciação, Nossa Senhora de Guadalupe e figurações da Virgem com o Menino em seus braços. Essa configuração imagética esteve também presente nas tradições hindus ${ }^{22}$ enquanto expressões das religiosidades locais. Para o nativo hindu colonizado e exposto à conversão católica em Goa, Nossa Senhora correspondia às imagens de Devi e às muitas faces das deusas.

Talvez não por acaso, os oragos das igrejas cristãs edificadas sobre os templos locais mimetizavam, na maioria das vezes, as funções anteriormente desempenhadas pelas divindades locais. Em que medida é que as Nossas Senhoras da Saúde Ide Margão, Sancoale, Cuncolim), do Socorro (de Sirula, Nagoa, Carmona), dos Remédios (de Nerul, Betalbatim, Cansaulim), das Flores (de Gonsua), do Amparo (de Mandur), da Ajuda (de Chimbel), da Piedade (de Dívar), mas também das Mercês (de Morumbim, Colva), da Graça (de Chorão), da Esperança (de Candolim, Chinchinim) eram percebidas como novos rostos das divindades locais que, como é sabido, desempenhavam múltiplas funções, nomeadamente a deusa Santeri, que tinha uma grande expressão nos territórios de Goa. (XAVIER, 2008, p. 264)

Desse pressuposto é que deve se inferir sobre a interligação entre Nossa Senhora e o Menino e a deusa Devaki-Krishnal, ${ }^{23}$ divindade introduzida nos territórios de Goa por devotos vishnuítas. Seu culto esteve vinculado à Krishna por ser sua Mãe, e suas imagens representadas com Balakrishna em seus braços, um pequenino em proteção maternal. Na vertente shivaíta, contudo sem a criança, sua correspondência está em Bhaukadevi, cuja natureza se reportava à reprodução biológica. Essa perspectiva foi examinada por Xavier (2008, p. 277-331) em estudos sobre os templos e as aldeias da llha de Chorão, nos domínios de Goa. A autora, sobre as confluências e encontros das representações marianas, inferiu que:

De facto, uma boa ilustração desta capacidade cumulativa lque remete, em última análise, para o encontro não só entre línguas mas também entre sistemas de representação distintos, não coincidentes nas suas formas de classificaçãol foi o modo como a mãe de Cristo - exemplo já referido, várias vezes - viria a ser representada. As populações locais estavam habituadas a uma grande multiplicidade de divindades femininas, as quais, por sua vez, tinham formas distintas e expressões por vezes contraditórias. Esta grelha referencial facilitava, por exemplo, a inclusão das "deusas" cristãs (caso das expressões diversas de Maria e de outras santas), atribuindo-lhes significados e funções bem familiares. Nada mais simples. É claro, porém, que nem essas deusas, nem Maria, permaneceriam as mesmas. A flexibilidade tornar-se-ia um traço identitário no cristianismo sincrético surgido localmente, e talvez nada mais se esperava dos "mais rudes", quem se julgava bastar ensinar as noções mais básicas, a versão de bolso da fé cristã. (XAVIER, 2008, p. 324)
22. Em sua complexidade, o hinduísmo precisa aqui ser interpretado como um sistema religioso heterogêneo dotado de vários antagonismos, razão pela qual se faz necessário distinguir as religiões védicas, de onde virá o bramanismo, com as religiões dravídicas, próprias do sul do subcontinente indiano; este é o hinduísmo da Goa setecentista. Nesta multiplicidade não há fragmentação, mas transmutação. Na perspectiva da colonização, um conjunto unificado por uma mesma estética e crença.

23. Para algumas escolas, Devaki é uma semideusa já que somente Krishna pode ser o divino em plenitude. 
24. Atualmente, Universidade Estadual Paulista "Júlio de Mesquita Filho" - Unesp, Campus Marília.
Desse modo, entende-se que, para o estudo da produção da imaginária em marfins da Índia, a dimensão mitológica, assim como as dimensões artísticas e sociorreligiosas, torna-se fundamental para a sua interpretação e para as análises simbólicas. As implicações desses hibridismos (influências de representações religiosas nas esculturas de marfim) fizeram-se visíveis nas proibições e medidas administrativas vigentes quando do 10 Concílio Provincial, em 1567, na Sé de Goa. Assim como os pintores locais, não cristãos, que foram proibidos de pintar imagens divinas, ou como os artesãos e ourives locais que foram impedidos de construir estátuas utilizadas no culto cristão (XAVIER, 2008, p. 264), os escultores do marfim e suas produções, que também sofreram sanções, viram-se movidos pelo crescente consumo europeu, ávido por produtos de luxo, além dos colecionadores de objetos considerados exóticos e de manufaturados do Oriente, em suas circulações de cultura material, apesar das impostas restrições da fatura artesanal. As imagens marianas e todo o seu simbolismo refletem e retratam dados que nos levam ao contexto dessas relações híbridas durante o período de expansão do Império português. A atividade dos artesãos goeses explorada pelos portugueses escoou pela Europa e pelas Américas uma série de representações de Maria. Essas imagens marianas, como vimos, também guardam as marcas do sagrado feminino para os hindus.

Os marfins da Índia nos circuitos de Goa à Bahia: iconografias de arte colonial

Em abril de 1966, o então jovem historiador José Roberto do Amaral Lapa defendia a sua tese de doutoramento (LAPA, 2000), orientado por Sérgio Buarque de Holanda, na Faculdade de Filosofia, Ciências e Letras de Marília. ${ }^{24}$ Seu trabalho, um amplo e profundo estudo desenvolvido e tomado por base de uma rigorosa pesquisa em arquivos brasileiros e portugueses, além da Biblioteca Nacional de Madri, teve como objeto o porto da Bahia e sua integração econômica com a carreira da Índia. Pela vastidão de dados e informações relativas à movimentação portuária em Salvador com a contínua presença das naus portuguesas regressas do Oriente, com o escoamento de produtos orientais na Bahia, em Pernambuco e no Rio de Janeiro e a circulação de mercadorias e dos diversos personagens lusitanos que transitavam entre os espaços coloniais, desde mercadores e navegantes a autoridades civis e religiosas, além de missionários, colonos, soldados e degredados, Amaral Lapa relacionou os diversos aspectos que compunham o quadro social baiano criado entre os séculos $\mathrm{XVI}$ e XVIII, com ênfase no comércio das naus e nas frotas da carreira. Para justificar os seus estudos, ele diz:

O descobrimento ou reconhecimento do Brasil, longe das controvérsias sobre a sua casualidade ou não, foi e aqui já não podem pairar dúvidas, um episódio da Carreira da Índia. Assim começa, oficialmente, nossa existência, indissoluvelmente vinculada ao grande roteiro que, tanto pelos seus antecedentes, como pelas suas repercussões - a aventura da Índia, e 
portanto a sua Carreira [...]. Mais ou menos na mesma ordem de ideias, queremos ainda registrar a completa ausência neste estudo de um capítulo que é bem possível ser desenvolvido sobre a "presença cultural" do Oriente no Brasil. [...] Preocupou-nos mais, dentro de um critério geral e, no caso, um tanto subjetivo, a importância do porto de Salvador, demonstrada no caso através da sua integração na Carreira. (LAPA, 2000, p. XIII-XVIII)

Ora, o culturalismo oriental observado por Amaral Lapa advém das possessões portuguesas na costa oriental africana, no mar Vermelho, em todo o subcontinente indiano, em Macau, na China, além dos contatos com os demais asiáticos, incluindo os japoneses. Dessa perspectiva, a obra de Amaral Lapa juntouse aos clássicos de Gilberto Freyre, nesse caso Sobrados e mucambos (FREYRE, 1981 1, com o capítulo intitulado $\bigcirc$ Oriente e o Ocidente, que em 1936 trouxe uma contribuição ímpar para os estudos culturais do Brasil, já iniciados por Freyre em 1931, com Casa-grande \& Senzala (FREYRE, 2006).

Fundamentado nos dois grandes autores e inspirado nas pesquisas de Russel-Wood (1992) e Anthony (2004), a circulação de imagens em marfins da Índia no espaço colonial brasileiro vinculada aos principais portos, a partir da Bahia, constituiu um elo indissociável da Carreira da ĺndia e da inclusão do porto baiano na rota intercontinental.

Por ter sido o berço do Brasil colonial, a cidade de Salvador assumiu papel estratégico nas relações comerciais com a Coroa portuguesa devido a sua condição de sede do império nas terras do novo mundo. Das rotas oceânicas traçadas pelos portugueses no projeto expansionista, a Carreira da Índia foi a mais importante via das Grandes Navegações. O seu percurso compreendia a viagem de Lisboa a Goa e vice-versa, passando pela Bahia e por alguns espaços coloniais na África, evidenciando o multiculturalismo no Império português. Com as naus abastecidas na Índia, com produtos advindos dos inúmeros entrepostos do Oriente, e de volta a Portugal um largo fluxo de mercadorias, lícitas e ilícitas chegou a Salvador, inserindo no Brasil itens orientais, numa experiência de alteridade, um diálogo entre civilizações através de aspectos artísticos, culturais e econômicos das tradições portuguesas com os povos do Oriente. É possível identificar na imaginária barroca, na gastronomia, no comércio e nos costumes, a presença luso-oriental na gênese cultural do Brasil colonial. Especiarias, têxteis, obras de arte, técnicas agrícolas e tecnologias de embarcação passaram a compor um quadro social na Bahia e nos instiga à revisão desse processo histórico. A iconografia em marfim da coleção do Museu de Arte sacra da Bahia, além dos documentos relativos à atuação dos missionários jesuítas na Índia e na Bahia, atesta tais dinâmicas de interações intracoloniais, um mecanismo de integração socioeconômica.

Quase todos os museus da Bahia dedicam uma seção dos "marfins goaneses", que aportam em quantidade nos séculos XVII e XVIII - com ou sem policromia, mesclados ou não com detalhes em madeira, com ou sem realce de pormenores em dourado. Copiadas de modelos europeus, mas de inspiração e espírito decorativo essencialmente indianos, estas imagens de 
25. Sobre essa iconografia ver os estudos de Patrícia de Souza Faria (2004), Edjane C. Rodrigues da Silva (2009) Maria Cristina Osswald (1996), Jorge Lúzio Matos Silva (2011). pequeno vulto se destinavam sobretudo às capelas e oratórios particulares, atendendo ao culto familiar. (MUHANA, 2003, p. 46-47)

Essa iconografia reproduziu a religiosidade católica nas imagens do Cristo, em várias representações, e dos santos, de um modo especial as de Nossa Senhora apresentada em seus principais cultos, Nossa Senhora da Conceição e Nossa Senhora do Rosário, além dos santos Antônio, Francisco de Assis, José, João Batista, João Evangelista, Inácio de Loyola, Francisco Xavier, Madalena e Ana. Em todos os casos, a técnica e a estética barroca do marfim revelavam os seus criadores, os artesãos indianos que criaram um novo padrão de representação das figuras religiosas, com traços étnicos não europeus. A imagem do Menino Jesus Bom Pastor ${ }^{25}$ em códigos orientais, as vestes femininas das santas com barrados e bordados a lembrar os sáris - veste típica das mulheres da Índia -, os olhos fortemente amendoados e os cabelos mais ondulados que os normalmente vistos nas imagens produzidas na Europa, apontam para uma outra origem de criação, visivelmente oriental. Junto a elas, muito mais se via ao ser constatada a utilização da pimenta e das especiarias na gastronomia regional da Bahia, perpetuadas pelo passado colonial, e a circulação dos produtos têxteis, entre outros, fluindo naturalmente nas residências abastadas da cidade de São Salvador da Bahia no século XVII.

A colônia do Brasil visivelmente absorvia os desejados produtos das Índias - ainda que fossem ilícitos, haja vista a proibição das negociações e do comércio entre as colônias, pois só era permitida a relação direta com a Coroa portuguesa, que distribuía as mercadorias entre as suas possessões, numa ação que visava ao controle do comércio ultramarino.

As naus da Índia, de volta de Macau e Goa, é que enchiam a Bahia de colchas de preciosa tela [...]. A bordo dos barcos vendiam os tripulantes, por preços ínfimos, esses pequenos tesouros do oriente, que não havia marinheiro que não carregasse de Ormuz e Calicut, adquiridos ninguém sabe como. Graças à humildade dos preços é que toda a gente ali se cobria com as colchas indianas, que também serviam, nos dias festivos, assim no de Corpus Christi como no da Senhora da Conceição, para engalanarem as janelas, derramadas para fora, a revestirem as paredes negras. (MUHANA, 2003, p. 42)

A Carreira foi o evento histórico responsável pela integração comercial que descentralizou a movimentação econômica do Mediterrâneo e inaugurou vínculos culturais e mercantis entre novos povos, através do intercâmbio das dezenas de produtos de origem indiana que, como mercadorias de forte apelo comercial, encontraram em Salvador um importante porto de escala, consumo e comercialização. Além da pimenta, alvo principal da demanda europeia, dezenas de outros itens tornaram-se demasiadamente valiosos, gerando negócios altamente lucrativos, entre eles o marfim. O Recôncavo Baiano, partícipe desse contexto, recebeu uma ampla gama de produtos e elementos da cultura da Índia portuguesa, no momento em que interagia, com os missionários, em maior parte jesuítas e 
franciscanos que se revezavam nas missões catequéticas, e com os marinheiros portugueses que atuavam na manutenção das naus e das embarcações no estaleiro do porto de Salvador. Esse porto foi incluído para reabastecimento nas viagens da Carreira da Índia, e para os reparos técnicos das naus, haja vista o uso dos recursos madeireiros nos consertos das embarcações, que atracavam na Bahia muitas vezes com danos provenientes das longas permanências nos mares.

A designação de Carreira da Índia [...] compreende o roteiro e os navios portugueses, oficiais ou particulares, que dele se serviram no desenvolvimento que Portugal manteve com o Oriente durante determinado período. É, portanto, a rota marítima de Lisboa a Goa e vice-versa, através do Atlântico e do Índico. Não é outro o significado que a designação toma no documentário da época. (LAPA, 2000, p. XIV-XV)

contato dos mercantes lusos com o marfim já estava consolidado. ${ }^{26}$ Em contraponto, os missionários viram nas imagens religiosas em marfim um rentável volume de objetos artísticos e uma arte sacra estrangeira de brio diverso, ora para atender a uma efervescência religiosa nos países europeus em resposta à Contrarreforma e pela implantação da cultura cristã nas terras conquistadas, ora para criar possíveis instrumentos de catequese e persuasão ${ }^{27}$ na conversão dos povos pagãos absorvidos pelo Império, numa dinâmica ambígua que indica a prevalência do aspecto econômico sobre o religioso. Os missionários das ordens que atuaram no Oriente, de um modo particular os jesuítas, ${ }^{28}$ desenvolveram um método de transformar a arte em marfim numa combinação entre comércio e fé, que implicou a utilização da mão de obra artesã dos escultores e de seus ateliês familiares nas possessões lusitanas na Índia centradas em Goa. A iconografia denominada indo-portuguesa ${ }^{29}$ foi copiada de imagens europeias por artesãos indianos, com matéria-prima oriental, marfim, esculpido em presa pura ou posteriormente policromado, íntegro ou acrescido de metal e pedras preciosas, desenvolvido, como já visto, em grande parte nas oficinas indianas na Índia portuguesa.

A evangelização iniciada no Estado da Índia no início do século XVI encontrou na plurietnicidade sociorreligiosa a predominância dos grupos hindus no milenar sistema de castas. Entretanto, o encontro histórico hinduísmo/ cristianismo ocorreu no século IV d.C. na costa do Malabar, atual estado de Kerala, extremo sul da Índia, e no Sri Lanka, antigo Ceilão. A penetração maciça dos missionários, franciscanos, jesuítas e dominicanos, entre outros, que posteriormente adentraram em todo o subcontinente, iniciou a evangelização entre as castas inferiores. Num segundo momento, a ação missionária chegou às aldeias e vilarejos, cristianizando agricultores e artífices até absorver os grupos socialmente superiores, os vanis, que se ocupavam do comércio, os maratas, oriundos da fusão de castas dos xátrias, os vaixias, que se consideravam descendentes dos arianos e se vinculavam às atividades militares e administrativas, e os brâmanes, nobres por excelência e que desenvolviam os ofícios sacerdotais e as funções educativas. Nessa hierarquia, a cristianização não conseguiu alterar
26. Ver as fontes manuscritas do Projeto Resgate, arquivos da Capitania da Bahia sobre o confisco de 1243 presas de marfim (AHU Bahia, cx. 15, doc 23) e o catálogo do acervo Alberto Lamego, disponível no IEB/USP, referentes ao século XVIII, apresentados em SILVA, 2011.

27. A crítica de Giulio Argan em Imagem e persuasão, 2004, na análise do barroco e na função das imagens na estrutura da sociedade moderna, é pertinente e serviu de balizamento para algumas discussões que aqui propomos.

28. As fontes utilizadas para a pesquisa também incluem a documentação jesuítica e obras que tratam de estudos sobre a Companhia de Jesus na Ásia. Sobre as outras ordens religiosas que atuaram na Índia nesse contexto, ver Patrícia de Souza Faria (2004)

29. Concebido numa perspectiva nacionalista, o conceito de "indo-português" traz em si limitações largamente discutidas, como já expôs Madalena de Cagigal e Silva, que viu no termo "... mais ou menos hesitações e restricções, tanto objetos de arte portuguesa com influência indiana, como obras de arte indiana com influência portuguesa" (SILVA, 1966). Em seu artigo sobre o discurso colonial no contexto das artes, Carla Alferes Pinto esclareceu sobre a recorrência de se atribuir o uso do termo ao jornalista português, de notável erudição, Francisco Marques de Sousa Viterbo que, apesar da crítica, também o utilizou em "Notas ao Catálogo da Exposição Retrospectiva de Arte Ornamental Portuguesa e Espanhola" em 1882 (PINTO 2016) É também visto como uma concepção dualista para abordar as interpenetrações Portugal e Índia no campo da historiografia, da 
literatura e das artes. De acordo com os estudos pós-coloniais, claro está que há uma necessidade de se atentar para o caráter ideológico deste conceito. as relações de poder, e mesmo as castas mais elevadas já convertidas mantiveram sua função social. Nessa configuração surgem novos grupos como os reinóis, lusitanos habitando na Índia ou luso-asiáticos de outras províncias e seus descendentes, e chardós, aristocratas rurais convertidos e em busca de ascensão social, provenientes da casta dos maratas, ou xátrias, por tradição, descendentes de guerreiros que rivalizavam com os brâmanes o acesso ao poder.

A circulação de presas do marfim africano proveniente de Moçambique com destino ao Gujarate, ao norte da Índia portuguesa ou a Lisboa no retorno das naus, e da estatuária goesa ebúrnea nas rotas do Império a partir de Goa, inseriuas na Bahia seiscentista, as quais foram rapidamente absorvidas pelas elites locais, pelas casas religiosas e conventos baianos que encontraram nas pequenas esculturas a devoção religiosa e a sofisticação artística, já que eram apresentadas na ambivalência do sagrado e do exótico. Sua comercialização foi favorecida pelos missionários em trânsito e pelos marinheiros e grumetes que clandestinamente as negociavam ainda nos portos a bordo das naus e respondiam ao consumo das elites coloniais. Os missionários promoveram tal intercâmbio e, dessa forma, a produção da imaginária foi se intensificando na Índia, chegando aos séculos XVIII e XIX e se estendendo a outras partes do território asiático português, fazendo surgir, além do indiano, o estilo cíngalo-português, com as oficinas do Ceilão, o sinoportuguês, de Macau, e mais raramente o nipo-português, com objetos do Japão. Pelo volume maior de peças indo-portuguesas e pela veemente dinâmica política e comercial estabelecida entre a Bahia e Goa, esta é uma abordagem delimitada nas relações intracoloniais entre tais províncias no âmbito da cultura e da religião, baseadas em estudos anteriores elaborados na dimensão econômica patriarcal baiana. Por isso se observaram os fluxos sociais que se desenvolveram a partir da circulação da referida iconografia, desde o momento em que o marfim se tornou sacralizado nas formas dos santos entre missionários jesuítas e os artesãos hindus cristianizados - e mesmo os casos de artistas não convertidos, até o momento em que se vê entre a gente do mar e a população soteropolitana, num movimento de interculturalidade colonial.

○espaço marítimo foi extensão da urbe portuguesa. Castelos, púlpitos, naus, portos, vilas e aldeias integraram as partes de um cenário que abrigou os eventos da expansão marítima lusitana e aproximou pela língua e pelo mar as mais diversas áreas do Atlântico, Índico e Pacífico, permeando a onipotência da cultura portuguesa, no que conhecemos por colonialismo. E se de modo feroz se alastrou em seu poder político, subjugando os povos conquistados, por eles foi marcado pelos resultados das fusões e influências que ocorreram, entre outros, no campo da cultura. A produção artesanal não permaneceu incólume nessa profusão e choque entre povos e poderes, e foi significativamente se redefinido, em cada novo chão em que se criou. A imaginária denominada "indo-portuguesa" - embora seja pertinente na esteira do criticismo colonial a releitura do conceito como "marfins da Índia" - ratificou o fenômeno da colonização enquanto vetor de integração de linguagens artísticas, outrora díspares, então síntese do encontro de culturas. 
Assim, está no jesuitismo e nas demais ordens religiosas, assim como nos desafios da missionação, a chave para se compreender as razões que levaram o comércio do marfim para o altar e de lá para as religiosidades de cristãos e cristianizados no Oriente e na América portuguesa. As naus nesse contexto foram embarcações comerciais e navios de guerra, mas foram também as naves da fé, que levaram, além do evangelho de Jesus Cristo e seus propagadores, emblemas e imagens sem esconder o seu real interesse no projeto de aquisição de almas e bens, a serviço da religião e de um estado a ela subalterno. A ideologia cristã e os proveitos das instituições religiosas junto à avidez da Coroa e das elites lusitanas aportaram, sob a égide da Cruz, nas aldeias e portos africanos, onde o marfim foi fartamente comercializado e de lá moldado, na África ou na Índia, para atender às expectativas de ganhos e lucros. Infiltraram-se entre os habilidosos artesãos do Oriente, que trouxeram no conhecimento passado por gerações o primor de uma sofisticada técnica de esculpir, todavia para servir ao conquistador e atender a seus ganhos e propósitos. $\bigcirc$ missionário foi o ator social que melhor cumpriu o papel da dominação, pois foi sagaz e sutil ao persuadir e conquistar. Dessa relação, missionário e artesão, despontaram as primeiras sociabilidades que emergiram no surgimento da iconografia em marfim. Sem dúvida, algo que resguardou a complexidade de uma análise histórico-antropológica e que se resumiu pela dialética da colonização. $\bigcirc$ mosaico cultural que era a chamada ĺndia portuguesa, - leque amplo de castas e etnias que integraram o quadro social indiano, visivelmente mesclado por hindus e muçulmanos e tracejado com contornos budistas, jainistas, pársis, judeus e mesmo de cristãos orientais, formou uma sociedade híbrida (CANCLINI, 1998) que trouxe a hibridização em sua própria realidade que, se era difusa por natureza, também era condensada e convergente, formando o paradoxo que ainda é a Índia como um todo.

As representações cristãs em marfim evidenciaram o contexto socioeconômico e deixaram claros os artifícios políticos presentes no ambiente em que foram produzidas. Essa abordagem é indispensável para uma leitura histórica. No entanto, há uma magnificência na forma e no padrão estético, preenchidos por uma rica simbologia oriental ${ }^{30}$ que prevaleceu para uma observação mais crítica da estatuária, proporcionando novas descobertas - distantes de uma visão eurocêntrica, e um olhar que incita a percepção da alteridade. Esse aspecto é relevante para a discussão proposta, já que possibilita uma reflexão diacrônica sobre a diversidade cultural, indispensável aos estudos contemporâneos. As bases das tradições cristãs e hindus foram assim representadas numa perspectiva simbólica do sagrado na reflexão sobre um hibridismo cultural, naquilo que é discutido em um continuum cultural, como observou Burke (2003, p. 14). $\bigcirc$ entendimento sobre o significado de cada linha facial das imagens, os traços orientais na fisionomia dos santos, a sinuosidade dos seus corpos, as dobraduras e os caimentos das vestes, posições de pernas, tronco, mãos e formato dos cabelos cedem ao conflito de oposições espirituais e estéticas e genialmente criam, de modo harmônico, um novo modelo de arte sacra.
30. Para esta análise, foram empregados os conceitos de Clifford Geertz (1989) e de Ananda Coomaraswamy (1992). 
31. Referência ao consumo dos "exotismos" do Oriente, sinônimo de status para as elites patriarcais, segundo as narrativas de Gilberto Freyre (1981) e de Victor Leonardi (2005).

32. De acordo com os estudos pós-coloniais, este é um termo que requer revisões e debates, ante às discussões nacionalistas, à crítica colonial, ao orientalismo e aos subaltern studies. expansionismo europeu e a mercantilização advindas dos grandes descobrimentos proporcionaram a movimentação de um grande fluxo de mercadorias que transitavam entre a metrópole e as colônias através de redes comerciais. As rotas transoceânicas, a nova tecnologia naval refletida nas grandes naus e galeões e a exploração de portos criaram o comércio ultramarino e foi por ele que as esculturas chegaram à Europa. Todavia, os produtos do Oriente escorreram de diversas formas pelas redes do império marítimo. Em se tratando das imagens em marfim, sabemos que elas aportaram no Brasil por meio de três possíveis canais de compra: pelas redes de comércio ilegal, que consistia em práticas comerciais clandestinas (FERREIRA, 2010) e que ocorriam com a conivência de autoridades locais na compra dos têxteis das diversas regiões produtoras da Índia para utilização nas demais praças e províncias, além da própria metrópole. Da mesma maneira, especiarias, sementes, utensílios, tapetes, móveis, pedras preciosas e manufaturas também eram negociados. Outra forma de distribuição, de acordo com Almeida (2003, p. 189), teria sido pelas liberdades que marinheiros traziam como parte dos seus proventos, caixas carregadas de produtos que thes era permitido negociar. Essas caixas acomodariam facilmente as estatuetas, que entre tecidos e especiarias viajavam no porão das naus portuguesas e, lá mesmo, ancoradas nos portos da Carreira, proporcionavam a comercialização; e, finalmente, entre os pertences de missionários e autoridades religiosas.

$\bigcirc$ porto de Salvador, que movimentava um grande número de embarcações entre a Europa, a América e a África, recebia frequentemente os navios da Carreira da Índia, que, em alguns momentos, viram-se proibidos em fazer escala na Bahia por política da Coroa de combate ao contrabando que ali, como também noutros portos dos domínios lusitanos, era constante. Por força maior, muitas naus ancoravam na ribeira das naus, no Recôncavo Baiano, pelas necessidades dos reparos estruturais dos navios e pelos danos causados pelos longos períodos no mar. Somente após as estadias dos navios em águas baianas, e devidamente refeitas, poderiam concluir o "torna-viagem" de volta à Lisboa. É nesse ínterim que grandes levas de mercadorias do Oriente foram absorvidas pelas cidades de Salvador e posteriormente pelas do Recife e Rio de Janeiro, do final do século XVI a meados do XVIII, quando a Carreira da Índia começa a dar indícios de sua derrocada comercial.

Algumas abordagens já foram feitas por renomados pesquisadores; entretanto observou-se que o circuito dos produtos e mercadorias das Índias não só abrangia apenas a sua inserção nas práticas culturais como foi além, recriou um padrão comportamental, ${ }^{31}$ sugerindo o pensar na existência de uma identidade lusotropical ${ }^{32}$ entre as colônias, em vez de uma identidade destas em particular com a Coroa. A circunferência do trópico que enlaça o território colonial brasileiro com a África e o Oriente sustentou o formato de uma nova cultura, não mais genuinamente portuguesa, e sim mestiça, levando à miscigenação brasileira no período colonial à inclusão dos elementos étnicos luso-afro-orientais, não mais restrita apenas à presença exclusiva do europeu somado ao indígena e estes ao 
africano. Trata-se de rever os parâmetros em que se configura a sociedade colonial brasileira, e o quanto ela foi moldada nas relações com a Índia portuguesa. Esse fenômeno ficou mais claro no século XIX, quando as elites patriarcais brasileiras buscaram redesenhar a imagem do Brasil, tomando como modelo cultural a França da belle époque e a Inglaterra vitoriana, dissociando-o dos seus alicerces coloniais afro-orientais, vistos com menosprezo, de modo antiquado e rudimentar, numa explícita tentativa de inferiorização das culturas periféricas do Império português, até porque o lusitano que transita ou se estabelece no Brasil colonial é um sujeito influenciado - quando não miscigenado - pelos povos com os quais ele passou a conviver.

As relações intracoloniais entre Bahia e Goa duraram mais de dois séculos, até que a falência da Carreira da Índia (o elo entre as colônias portuguesas), resultada pelos custos dispendiosos e pelo alto número de naufrágios, além das alterações no quadro político do Império português na Índia, inviabilizou no Brasil a continuação daquele intercâmbio comercial, pois as mesmas naus, quando da viagem de ida para Goa, levavam do Brasil itens que foram introduzidos em Goa, Diu ou Cochim, sendo o tabaco e o açúcar os mais conhecidos. As ligações entre as duas colônias deixaram um saldo significativo na história do Brasil colonial, o qual oferece aos pesquisadores argumentos que reforçam as afinidades de um momento histórico comum.

Goa e Salvador rivalizaram influências e poder político no Império português no século XVII. De suas relações, a capital baiana tinha maior proximidade com Lisboa, e em função do crescimento da economia açucareira passou a atrair maior atenção das elites portuguesas e um consequente crescimento na atividade portuária.

\begin{abstract}
A cidade era a cabeça política e administrativa da colônia americana; possuía bom ancoradouro, relativamente abrigado; ficava aproximadamente no meio da extensa orla litorânea; estava mais perto do reino que os portos do sul; oferecia facilidade de contato com as colônias da África ocidental portuguesa, estimulado pelo tráfico de escravos; exportava entre outros produtos tabaco, açúcar, madeiras, especiarias e fibras tropicais; era de fácil acesso para abastecimento e refresco dos navios; apresentava recursos em matérias-primas e proporcionava eventuais socorros de sua praça de guerra. (LAPA, 2000, p. 2)
\end{abstract}

A Carreira foi o evento histórico responsável pela integração comercial que descentralizou a movimentação econômica do Mediterrâneo e inaugurou vínculos em cultura e mercantilização entre novos povos, haja vista o intercâmbio das dezenas de produtos de origem indiana que, como mercadorias de forte apelo comercial, encontraram em Salvador um importante porto de escala, consumo e comercialização.

As imagens marianas estudadas neste artigo expressam os vínculos culturais e econômicos desenvolvidos durante a expansão do Império português, e são por isso um modelo novo de arte sacra. Esse modelo, perceptível a uma leitura crítica da realidade histórica do Império português, traz as marcas dessa realidade, 
seja no marfim talhado pelos artesãos goeses, seja na indumentária com a qual Maria era representada para aquela realidade, seja nos símbolos sincretizados. De todo modo, por ser a figura religiosa feminina historicamente mais representada, em suas peculiaridades estarão a presença de cada cultura que a representou, em suas correlações e interpretações, na convergência de um feminino sacralizado como um fenômeno de todos os povos.

\section{REFERÊNCIAS}

ALMEIDA, Anita C. L. de. Entre o Atlântico e o Índico: notas para uma história interligada. In: LOUNDO, Dilip; MISSE, Michel (Orgs.). Diálogos tropicais Brasil e Índia. Rio de Janeiro: Editora UFRJ, 2003.

ANTHONY, Philomena Sequeira. The Goa Babia intra-colonial relations - 1675/1825. Tellicherry: Irish, 2004.

ARGAN, Giulio Carlo. Imagem e persuasão: ensaios sobre o barroco. São Paulo: Companhia das Letras, 2004.

BENJAMIN, Walter. Obras Escolbidas - magia e técnica / arte e política: ensaios sobre literatura e história da cultura. São Paulo: Brasiliense, 2008.

BOFF, Leonardo. O rosto materno de Deus. Petrópolis: Vozes, 1979.

BOYER, Marie-France. Culto e imagem da Virgem. Tradução de Paulo Neves. São Paulo: Cosac Naify, 2000.

BOXER, Charles. A Índia portuguesa em meados do século XVII. Lisboa: Edições 70, 1980.

BURKE, Peter. Hibridismo cultural. São Leopoldo: Unisinos, 2003.

CAMPBELL, Joseph. As máscaras de Deus. Mitologia ocidental. São Paulo: Palas Athena, 2008.

CANCLINI, Néstor García. Culturas Híbridas: estratégias para entrar e sair da modernidade. São Paulo: EDUSP, 1997.

COOMARASWAMY, Ananda. A interpretação de símbolos. In: O que é civilização. São Paulo: Siciliano, 1992.

DIAS, Pedro. História da Arte portuguesa no mundo (1415-1822). O Espaço do Índico. Navarra: Círculo de Leitores, 2008. 
ELIADE, Mircea. O sagrado e o profano. A essência das religiões. São Paulo: Martins Fontes, 2001.

FARIA, Patrícia de Souza. A cultura barroca portuguesa e seus impactos sobre os espaços coloniais: política e religião na Índia Portuguesa. 2004. Dissertação de Mestrado - História, Universidade do Estado do Rio de Janeiro, Rio de Janeiro, 2004.

FERREIRA, Roquinaldo. "A arte de furtar": redes de comércio ilegal no mercado imperial ultramarino português (c.1690-c.1750) In: FRAGOSO, João; GOUVÊA, Maria de Fátima (Orgs.). Na trama das redes. Política e negócios no Império Português, séculos XVI-XVIII. Rio de Janeiro: Civilização Brasileira, 2010.

FREYRE, Gilberto. Oriente e Ocidente. In: Sobrados e mucambos. Decadência do patriarcado rural e desenvolvimento do urbano. 6. ed. Rio de Janeiro: José Olympio, 1981.

- Casa-grande E senzala: formação da família brasileira sob o regime da economia patriarcal. São Paulo: Global, 2006.

GEERTZ, Clifford. A interpretação das culturas. Rio de Janeiro: LTC, 1989.

JANSEN, Eva Rudy. O livro das imagens hinduístas: os deuses e seus símbolos. São Paulo: Totalidade, 1993.

JOÃO. Português. In: Bíblia de Jerusalém. São Paulo: Paulus, 2008.

LAPA, José Roberto do Amaral. A Babia e a Carreira da Índia. Campinas: Hucitec/ Unicamp, 2000.

LEONARDI, Victor. Os navegantes e o sonbo. Presença do Oriente na História do Brasil. Brasília: Paralelo 15 Editores, 2005.

LUCAS. Português. In: Bíblia de Jerusalém. São Paulo: Paulus, 2008.

MAIA, Pedro M. O Museu de Arte sacra da Universidade Federal da Babia. São Paulo: Banco Safra, 1987.

MATEUS. Português. In: Bíblia de Jerusalém. São Paulo: Paulus, 2008.

MATTEO RICCI no Império do Meio. Sob o signo da amizade. Revista do Instituto de Humanitas Unisinos, São Leopoldo: Universidade do Vale dos Sinos, n. 347, ano X, 18 out. 2010.

MUHANA, Adma. Brasil: Índia Ocidental. Revista USP, São Paulo, n. 57, p. 42, mar./maio 2003.

NATYA SASTRA. The Natya Sastra of Bharatamuni. English Translation. Delhi: Sri Satguru Publications, 1986.

OSSWALD, Maria Cristina. O bom pastor na imaginária indo-portuguesa em marfim. 1996. Dissertação (Mestrado) - Faculdade de Letras, Universidade do Porto, 1996. 
PELIKAN, Jaroslav. Maria através dos séculos: seu papel na cultura. São Paulo: Companhia das Letras, 2000.

PINTO, Carla Alferes. A arte ao serviço do império e das colónias: o contributo de alguns programas expositivos e museológicos para o discurso de legitimação territorial. MIDAS: museus e estudos interdisciplinares (on line), 2016, n. 6. Disponível em: https://midas.revues. org/957, acesso em 20 dez. 2016.

RAVERI, Massimo. Hinduísmo. O culto da Deusa in Índia e Extremo Oriente: via da libertação e da imortalidade. São Paulo: Hedra, 2005.

ROBERTS, J. M. O livro de ouro da História do mundo. Da pré-história à Idade contemporânea. Rio de Janeiro: Ediouro, 2001.

RUSSEL-WOOD, Anthony John R. Um mundo em movimento: os portugueses na África, Ásia e América, 1415-1808. Lisboa: Difel, 1998.

SANTOS, Lucila Morais. A sagração do marfim. Rio de Janeiro: Museu Histórico Nacional; São Paulo: Iphan; Pinacoteca do Estado de São Paulo, 2002.

SHEARER, Alistair. The Hindu Vision. London: Thames and Hudson Ltd., 1993.

SILVA, Edjane Cristina Rodrigues da. Influência da iconografia indo-portuguesa na representação do Menino Jesus do Monte. In: ENCONTRO DA ASSOCIAÇÃO NACIONAL DE PESQUISADORES EM ARTES PLÁSTICAS, 18., 2009, Salvador. Transversalidades nas Artes Visuais. Programa de Pós-Graduação em Artes Visuais da Escola de Belas-Artes/UFBA. Anais... Salvador: Anpap, 2009.

SILVA. Jorge Lúzio Matos. Sagrado marfim. O Império português na Índia e as relações intracoloniais Goa e Babia, século XVII: iconografias, interfaces e circulações. 2-011. Dissertação (Mestrado) - História Social, Pontifícia Universidade Católica de São Paulo, São Paulo, 2011.

SILVA, Maria Madalena Cagigal e. A arte indo-portuguesa. Lisboa: Edições Excelsior, 1966.

SPENCE, Jonathan D. O Palácio da memória de Mateo Ricci: a história de uma viagem: da Europa da Contra- Reforma à China da Dinastia Ming. São Paulo: Companhia das Letras, 1986.

XAVIER, Ângela Barreto. A invenção de Goa. Poder imperial e conversões culturais nos séculos XVI e XVII. Lisboa: Imprensa de Ciências Sociais, 2008.

ZIMMER, Heinrich. Mitos e símbolos na arte e civilização da Índia. São Paulo: Palas Athena, 1989.

Artigo apresentado em 29/08/2016. Aprovado em 30/12/2016. 